\title{
Single Odors Differentially Stimulate Dual Second Messenger Pathways in Lobster Olfactory Receptor Cells
}

\author{
I. Boekhoff, ${ }^{1}$ W. C. Michel, ${ }^{2, a}$ H. Breer, ${ }^{1}$ and B. W. Ache ${ }^{2}$ \\ 'Institute of Zoophysiology, University of Stuttgart-Hohenheim, 7000 Stuttgart 70 , Germany and ${ }^{2}$ Whitney Laboratory and \\ Departments of Zoology and Neuroscience, University of Florida, St. Augustine, Florida 32086
}

\begin{abstract}
Quench-flow measurements are used to determine the subsecond kinetics of odor-induced changes in second messenger concentrations in lobster olfactory receptor neurons. Individual odors transiently and differentially increase the production of both adenosine cAMP and inositol 1,4,5-trisphosphate $\left(\mathrm{IP}_{3}\right)$ within $\mathbf{5 0}$ msec of odor stimulation. The ability of two different odors to stimulate CAMP and IP ${ }_{3}$ correlates with the odors' ability to excite and inhibit receptor cells physiologically. These results strengthen the proposition, heretofore based largely on evidence from cultured cells, that dual second messenger pathways mediate excitatory and inhibitory input to lobster olfactory receptor cells.

[Key words: chemical senses, sensory transduction, olfaction, second messengers, cAMP, inositol 1,4,5-trisphosphate, lobsterl
\end{abstract}

Odors are generally considered to activate olfactory receptor cells through G-protein-coupled receptors that elicit rapid and transient pulses of intracellular second messengers (for recent reviews, see Breer and Boekhoff, 1992; Ronnett and Snyder, 1992; Anholt, 1993). Attention has focused on two second messenger pathways, one mediated by adenosine cAMP and the other by inositol 1,4,5-trisphosphate ( $\left.\mathrm{IP}_{3}\right)$. cAMP- and $\mathrm{IP}_{3}$-mediated olfactory transduction cascades have been identified in three different species of animals (rat: Boekhoff et al., 1990; Breer et al., 1990; Ronnctt ct al., 1993; catfish: Bruch and Tecter, 1990; Restrepo et al., 1990; Kalinoski et al., 1992; Miyamoto et al., 1992; lobster: Fadool and Ache, 1992; Michel and Ache, 1992).

The presence of two second messengers in such phylogenetically diverse animals argues that having dual inputs plays a fundamental role in olfaction. Evidence that different odors elicit either a cAMP or an $\mathrm{IP}_{3}$ response in isolated rat olfactory cilia preparations within $50 \mathrm{msec}$ of stimulation (Boekhoff et al., 1990; Breer et al., 1990) implies that the two pathways work in parallel, not sequentially, and that the parallel inputs function in coding per se and not in adaptation or other cellular events that presumably should be independent of odor composition. Subsequent insight into the possible role of having two olfactory

\footnotetext{
Received June 30, 1993; revised Sept. 27, 1993; accepted Nov. 24, 1993.

This work was supported by NIDCD 1 R01 DC01655-01 and by Deutsche Forschungsgemeinschaft $\mathrm{Br} 712 / 10-2$.

Correspondence should be addressed to B. W. Ache, Whitney Laboratory, University of Florida, 9505 Ocean Shore Boulevard, St. Augustine, FL 32086.

aPresent address: Department of Physiology, University of Utah School of Medicine, Salt Lake City, UT 84108.

Copyright (C) 1994 Society for Neuroscience $0270-6474 / 94 / 143304-06 \$ 05.00 / 0$
}

second messengers came from physiological evidence demonstrating that in lobster olfactory receptor cells $\mathrm{IP}_{3}$ and cAMP transduction cascades drive opposing ionic conductances that, respectively, excite and inhibit the cells (Fadool and Ache, 1992; Michel and Ache, 1992). Opposite electrophysiological effects of different odors on the same olfactory receptor cell have been observed in other species (mudpuppy: Dionne, 1992; toad: Bacigalupo et al., in press; catfish: Ivanova and Caprio, 1992; squid: Lucero et al., 1992). Although second messenger mediation has not yet been investigated, the data cstablish the coexistence of two transduction pathways in these systems.

In olfactory cilia from rats (Boekhoff et al., 1990; Breer et al., 1990) and catfish (Restrepo et al., 1993) and in insect antennae (Breer et al., 1990), individual odors were found to stimulate rapidly and transiently either cAMP or $\mathrm{IP}_{3}$, but not both. In cultured rat olfactory receptor cells, however, odors that elevate cAMP can alsu increase the lumover of phosphoinositide over intervals of seconds to minutes (Ronnett et al., 1993). In the lobster, adors that excite one cell can inhibit other cells and vice versa (Michel et al., 1991). This finding implies that at least some individual odors should be able to stimulate both cAMP and $\mathrm{IP}_{3}$. Thus, the lobster would be an excellent system to evaluate further the coupling of odor receptors to second messenger pathways since there is a physiological basis for predicting and interpreting a lack of specificity in the coupling of receptors to cAMP and $\mathrm{IP}_{3}$.

We now report that at higher concentrations, individual odors rapidly and transiently elicit the formation of cAMP and $\mathrm{IP}_{3}$ in the outer dendrites of lobster olfactory receptor cells, and do so to different extents that correlate with the odors' ability to excite and inhibit the cells physiologically.

A preliminary description of these results appeared in abstract form (Ache et al., in press).

\section{Materials and Methods}

Material. Olfactory organs (lateral antennules) were excised from specimens of the Caribbean spiny lobster, Panulirus argus, collected in the Florida Keys. The organs were excised into ice-cold lobster saline (mM: $460 \mathrm{NaCl}, 13 \mathrm{KCl}, 13 \mathrm{CaCl}_{2}, 10 \mathrm{MgCl}_{2}, 1.7$ glucose, 3 HEPES, pH 7.4) for physiological experiments. Otherwise, the organs were excised into ice-cold storage buffer (mM: $50 \mathrm{KCl}, 12.9 \mathrm{CaCl}_{2}, 23.1 \mathrm{MgCl}_{2}, 25.6$ $\mathrm{MgSO}_{4}, 10$ Tris/ $/ \mathrm{OH}, 320$ sucrose, $\mathrm{pH} 7.0$ ) and frozen on dry ice within $4 \mathrm{hr}$ of excision for subsequent use in biochemical experiments.

Physiology. One-millimeter-long hemisections of the olfactory organ containing the olfactory sensilla (aesthetascs) were enzymatically cleaned with $0.25 \mathrm{mg} / \mathrm{ml} \mathrm{L}$-cysteine activated papain (Sigma type IV, $25 \mathrm{~min}$ ) and $1 \mathrm{mg} / \mathrm{ml}$ trypsin in calcium-free saline (Sigma type IX, $25 \mathrm{~min}$ ). After treatment the preparations were rinsed in lobster saline and maintained at room temperature until use. The preparations remained responsive for 8-12 hr. A preparation was wedged into a slot molded into 
Sylgard elastomer that formed the bottom of a combined recording bath/ olfactometer (Michel et al., 1991). The somata of the olfactory receptor cells projected up into the recording bath and the sensilla projected down into the olfactometer. The preparation was positioned in the crossarm of the " $H$ " style olfactometer between two parallel flows, one containing lobster saline and the other odorant. Either flow could be rapidly and transiently diverted through the cross-arm to stimulate or wash the preparation. Whole-cell, current-clamp recordings were obtained after forming gigaohm seals on the soma of the cells with borosilicate patch electrodes (Boralex, Dynalabs) with a tip diameter of $\sim 1 \mu \mathrm{m}$ filled with pseudointracellular solution (mM: $140 \mathrm{~K}$-acetate, $30 \mathrm{KCl}, 1 \mathrm{CaCl}_{2}, 696$ glucose, 11 EGTA, 10 HEPES, pH 7.0 with $\mathrm{NaOH}$ to $\sim 30 \mathrm{Na}$ ). The signals were amplified by a patch amplifier (Dagan $8900 ; 1 \mathrm{G} \Omega$ headstage), displayed on a digital oscilloscope (Nicolet 4094), and stored digitally using pCLAMP software (Axon Instruments).

Tissue preparation for biochemistry. An enriched preparation of outer dendritic membranes was obtained by manually scraping the olfactory sensilla (aesthetascs) from the thawed olfactory organs with a sharp scalpel. This and all subsequent operations were done at $4^{\circ} \mathrm{C}$. In order to extract membranes from the sensilla, the sensilla were frozen in liquid nitrogen immediately upon scraping, homogenized manually in a small mortar, resuspended in modified lobster saline (mM: $120 \mathrm{NaCl}, 5 \mathrm{KCl}$, 1.6 $\mathrm{K}_{2} \mathrm{HPO}_{4}, 1.2 \mathrm{MgSO}_{4}, 25 \mathrm{NaHCO}_{3}, 7.5$ glucose, $\mathrm{pH} 7.4$ ) containing an antiprotease cocktail as described by Dadi and Morris (1984), and centrifuged at $200 \times \mathrm{g}$ for $10 \mathrm{~min}$ to produce a pellet (P1) containing sensillar cuticle and a supernatant $(\mathrm{S} 1)$. The $\mathrm{S} 1$ was removed, and the P1 was resuspended in a small volume of hypotonic buffer (mM: 10 Tris/ $\mathrm{HCl}, 2 \mathrm{EGTA}, 3 \mathrm{MgCl}_{2}, \mathrm{pH} 7.4$ ), incubated in an ultrasonic water bath for $5 \mathrm{~min}$, and centrifuged again at $200 \times \mathrm{g}$ for $10 \mathrm{~min}$. The resulting supernatant (\$2) was removed, combined with the previous SI and centrifuged at $28,000 \times g$ for $30 \mathrm{~min}$. The resulting pellet $(\mathrm{P} 2)$ was resuspended in a small volume of hypotonic buffer to give a protein concentration of $0.5 \mu \mathrm{g} / \mu \mathrm{l}$ and stored at $-70^{\circ} \mathrm{C}$. Protein concentrations were determined according to Bradford (1976) using bovine serum albumin as a standard.

Determination of second messenger concentrations. A rapid-quench device with three syringes (Bio-Logic, Claix, France) was used to determine the subsecond kinetics of odorant induced changes in second messenger concentrations. Stopped-flow experiments were performed as described previously (Breer et al., 1990). Briefly, syringe I contained the resuspended P2 fraction in $60 \mu 1$ hypotonic buffer. Syringe II was filled with $165 \mu$ l of stimulant buffer (mм: $200 \mathrm{NaCl}, 50$ MOPS, 2.5 $\mathrm{MgCl}_{2}, 1$ DTT, <0.05\% Na-cholate, 10 EGTA, 1 ATP, 0.002 GTP, 3 $\mathrm{CaCl}_{2}$ to give a calculated free $\mathrm{Ca}^{2+}$ concentration of $0.012 \mu \mathrm{M}, \mathrm{pH} 7.4$ ) containing odors, which were diluted from stock solutions to the appropriate concentrations. The concentration of free $\mathrm{Ca}^{2+}$ was calculated by the method of Pershadsingh (1980); tissue $\mathrm{Mg}^{2+}$ and $\mathrm{Ca}^{2+}$ were not included in the calculation. All solutions were adapted to $30^{\circ} \mathrm{C}$. Syringe III contained a solution of $7 \%$ perchloric acid $\left(0^{\circ} \mathrm{C}\right)$. The reaction was started by mixing the contents of syringes I and II. After an appropriate incubation time, the reaction was stopped by quenching the samples with $100 \mu$ of perchloric acid from syringe III. Quenched samples were then assayed for second messenger concentrations. cAMP was determined by a cAMP binding protein assay (Tovey et al., 1974). IP 3 was measured using the receptor binding assay described by Palmer et al. (1989). Radioligand assay kits for cAMP and for IP $_{3}$ were supplied by Amersham.

Odors. A complex, natural odor mixture was prepared by mixing 2 gm of TetraMarin, a dried, flaked "fish food" (TetraWerke, Melle, Germany), into $60 \mathrm{ml}$ of lobster saline or stimulant buffer, as appropriate for physiology or biochemistry, respectively, centrifuging at $1400 \times g$ and filtering the supernatant through \#3 Whatman paper. The resulting extract was diluted the number of times indicated in the Results. Single component odors were prepared as $10 \mathrm{~mm}$ stock solutions of taurine or L-proline in lobster saline or stimulant buffer. The stock solutions were diluted to obtain the concentrations indicated in the Results. The amino acids were obtained from Sigma.

\section{Results}

As would be predicted if both cAMP and $\mathrm{IP}_{3}$ were olfactory second messengers in the lobster, TetraMarin extract, a complex, natural odor mixture, rapidly and transiently elevated levels of both substances in the outer dendrites (Fig. 1). The peak concentration of both $\mathrm{cAMP}$ and $\mathrm{IP}_{3}$ occurred approximately

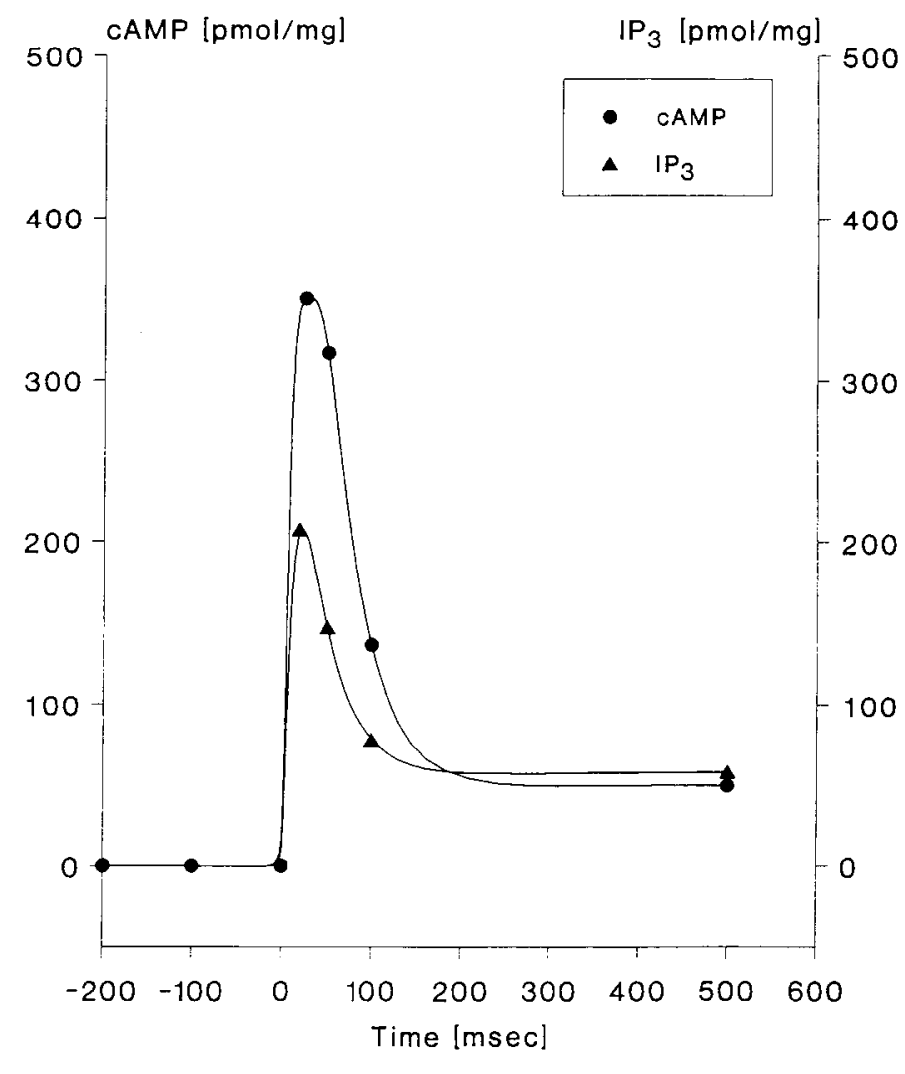

Tetra marin

Figure 1. Plot of the time course of stimulation of cAMP and $\mathrm{IP}_{3}$ in the outer dendritic membranes of lobster olfactory receptor cells by a 100-fold dilution of an extract of TetraMarin (see Materials and Methods for composition). Left ordinate, concentration ( $\mathrm{pmol} / \mathrm{mg}$ protein) of cAMP; right ordinate, concentration ( $\mathrm{pmol} / \mathrm{mg}$ protein) of $\mathrm{IP}_{3} ; a b-$ scissa, time (msec) before and after mixing the odor with the membranes at $t=0$. In this and all subsequent plots, the time before mixing reflects the basal level for each ligand, even though symbols are shown for only one of the ligands. Basal values were determined separately to be 81.5 $\pm 22.4 \mathrm{pmol} / \mathrm{mg}$ for cAMP and $325 \pm 46.4$ for $\mathrm{IP}_{3}(n=3$ in both instances). Each point represents the mean value of a minimum of three trials. Deviation from the mean was $<15 \%$ in all instances and is not indicated. Curves were fitted to the data by Harvard Graphics.

$50 \mathrm{msec}$ after mixing, with a half-peak duration of $70-80 \mathrm{msec}$. The peak concentration of cAMP $(360 \mathrm{pmol} / \mathrm{mg})$ produced by the TetraMarin extract was approximately five times the basal level of CAMP in this tissue, which was determined in a separate experiment to be $81.5 \pm 22.4 \mathrm{pmol} / \mathrm{mg}(n=3)$. The peak concentration of $\mathrm{IP}_{3}(200 \mathrm{pmol} / \mathrm{mg})$ was approximately 1.6 times the basal level of $\mathrm{IP}_{3}$, which was determined in a separate experiment to be $325 \pm 46.4 \mathrm{pmol} / \mathrm{mg}(n=3)$. The undefined, complex composition of the odor prevented determining if the same or different compounds within the odor mixture were elevating each signal. Therefore, an attempt was made to identify the ability of single-component odors to elevate cAMP and $\mathrm{IP}_{3}$.

The overall ability of single-component odors to excite or inhibit the receptor cell population is unknown. A preliminary physiological survey done as part of another study indicated that taurine frequently excited cells, whereas proline was frequently inhibitory (Michel et al., 1991). Taurine and proline therefore appeared to be candidate odors to activate the excitatory ( $\mathrm{IP}_{3}$ mediated) and inhibitory (cAMP mediated) pathways, 


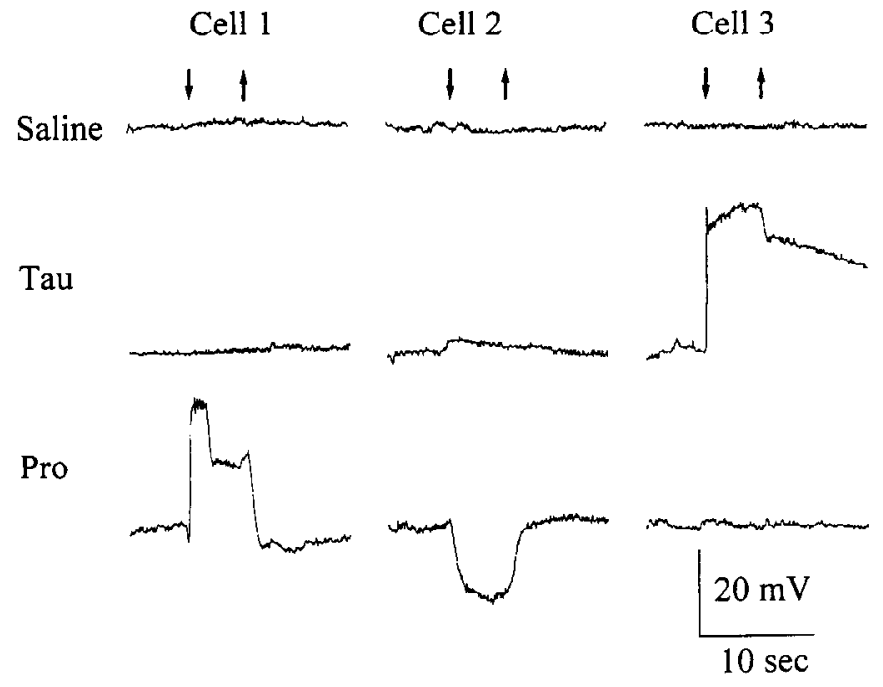

Figure 2. Typical whole-cell, current-clamp recordings from three lobster olfactory receptor cells. The resting potential of the cells was set to $-60 \mathrm{mV}$ prior to stimulation. One millimolar taurine and L-proline applied to the outer dendrites of the cells variously evoke depolarizing and hyperpolarizing receptor potentials. The cells vary in their pattern of sensitivity to the odors; they were either excited by one odor (Cells 1,3 ), inhibitcd by one odor (Cell 2) or excited by one and inhibited by the other odor (not illustrated). The latency of the receptor potential could not be determined accurately due to the dead volume of the olfactometer. Down and up arrows denote the onset and offset of odor stimulation, respectively.

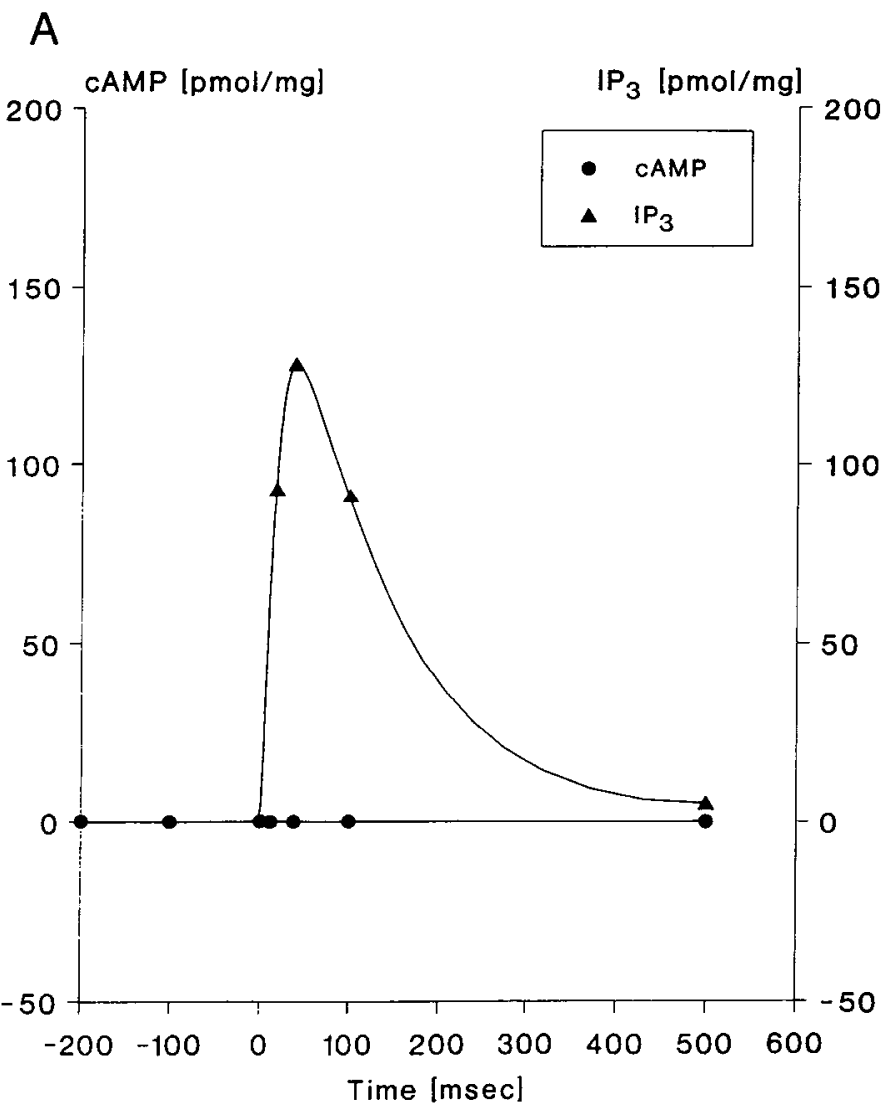

$1 \mu \mathrm{M}$ Taurine

$1 \mu \mathrm{M}$ Proline

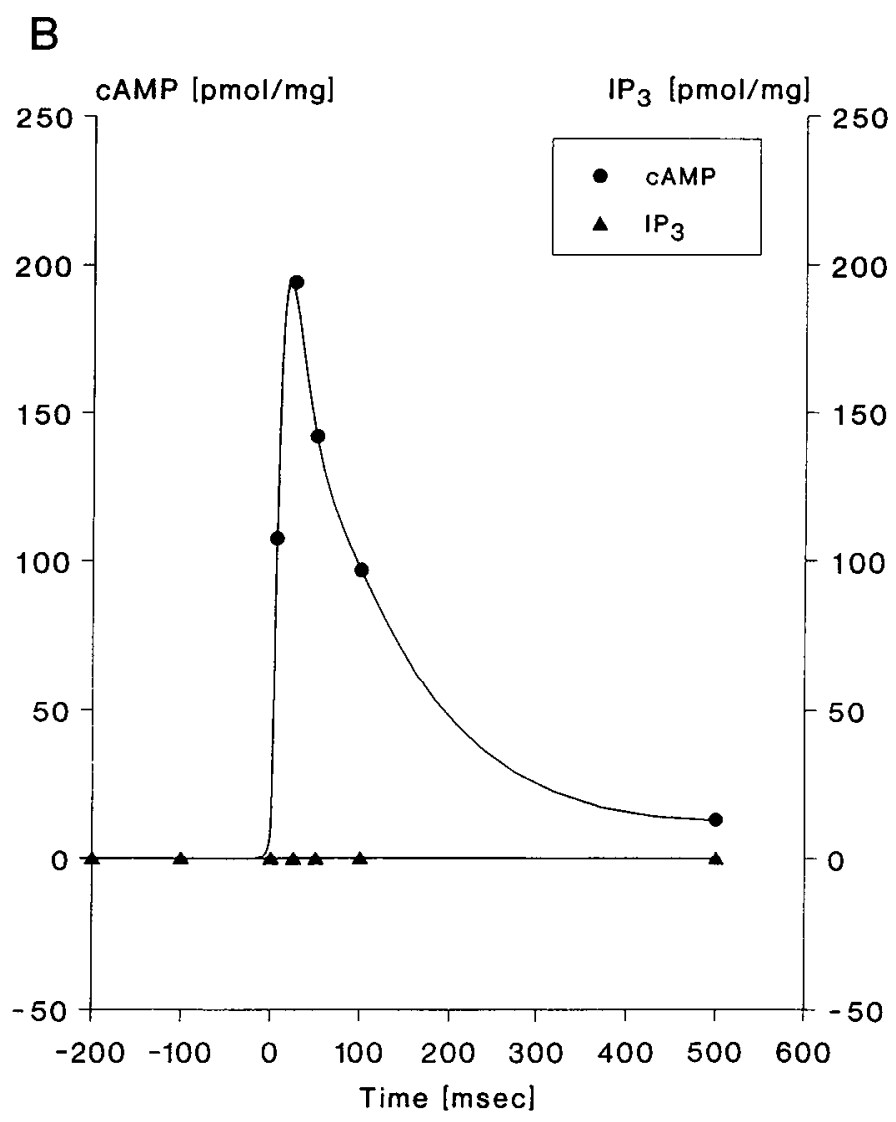

respectively. To better establish the extent to which taurine and proline are excitatory and inhibitory odors physiologically, we sampled a larger subset of the total receptor cell population than in the preliminary study (Fig. 2). At millimolar concentrations neither odor was exclusively excitatory or inhibitory, but the tendency for taurine to be excitatory and proline to be inhibitory seen in the preliminary survey was sustained. One millimolar taurine depolarized (excited) $31 \%$ and hyperpolarized (inhibited) $3 \%$ of 62 cells tested with this odor; it failed to stimulate $66 \%$ of the cells. One millimolar L-proline, in contrast, hyperpolarized $31 \%$ and depolarized $23 \%$ of 127 cells tested with this odor. The average magnitude of the depolarization evoked by taurine $(23.1 \pm 3.2 \mathrm{mV}, n=19)(X \pm \mathrm{SEM})$ was similar to that evoked by proline $(25.6 \pm 2.6 \mathrm{mV}, n=29)$, as was the average magnitude of the hyperpolarization evoked by taurine $(-10.2$ $\pm 5.8 \mathrm{mV}, n=2)$ and proline $(-11.4 \pm 6.3 \mathrm{mV}, n=39)$. These two single-component odors subsequently were evaluated at two different concentrations for their ability to elevate cAMP or IP . $_{3}$

One micromolar taurine stimulated the production of $\mathrm{IP}_{3}$, whereas the concentration of cAMP was unchanged (Fig. $3 A$ ). In contrast, micromolar proline induced a cAMP response, but in this case the level of $\mathrm{IP}_{3}$ was unchanged (Fig. $3 B$ ). Both signals peaked within $50 \mathrm{msec}$ of mixing, as was the case with the complex odor (Fig. 1). The peak concentration of $\mathrm{IP}_{3}(130 \mathrm{pmol} /$ $\mathrm{mg}$ ) stimulated by taurine and the peak concentration of CAMP (190 pmol/mg) stimulated by proline was less than that produced by the complex odor, presumably reflecting a lower ef-

Figure 3. Plot of the time course of stimulation of cAMP and $\mathrm{IP}_{3}$ in the outer dendritic membranes of lobster olfactory receptor cells by $1 \mu \mathrm{M}$ micromolar taurine $(A)$ and $1 \mu \mathrm{M}$ proline $(B)$. Coordinates are labeled as in Figure 1. 
A

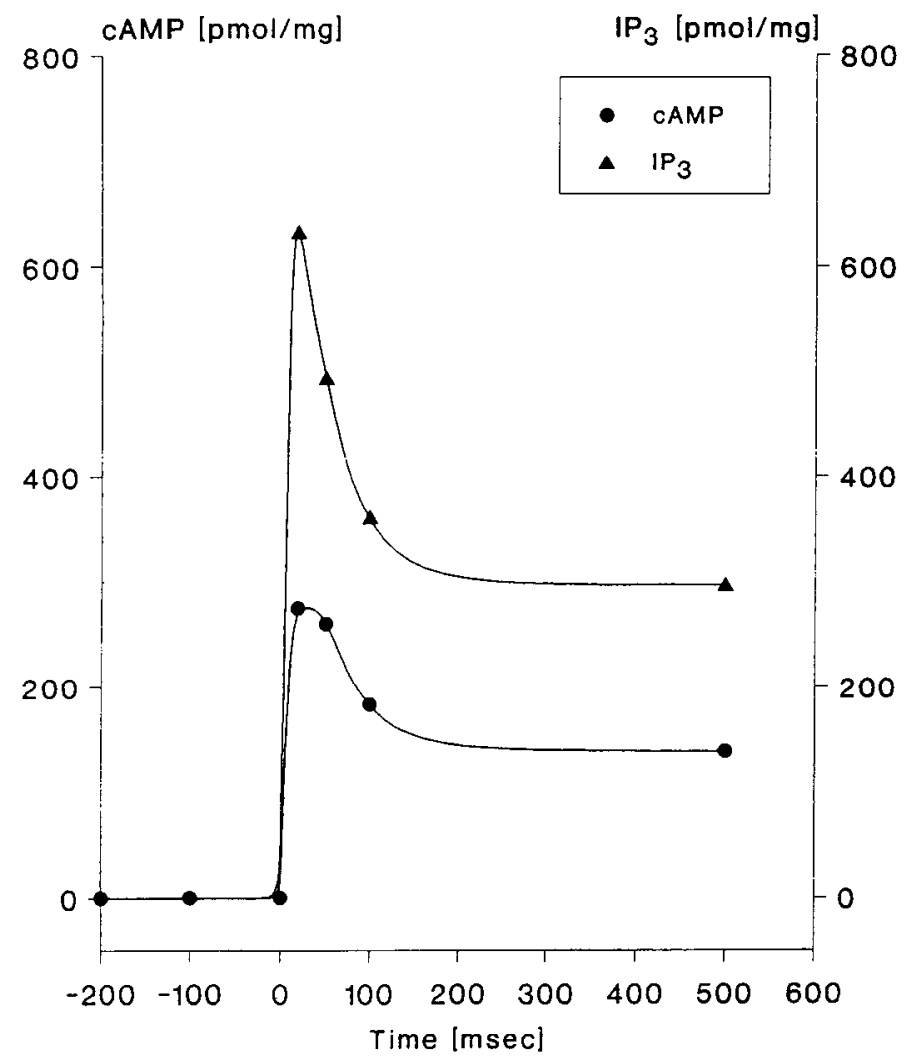

B

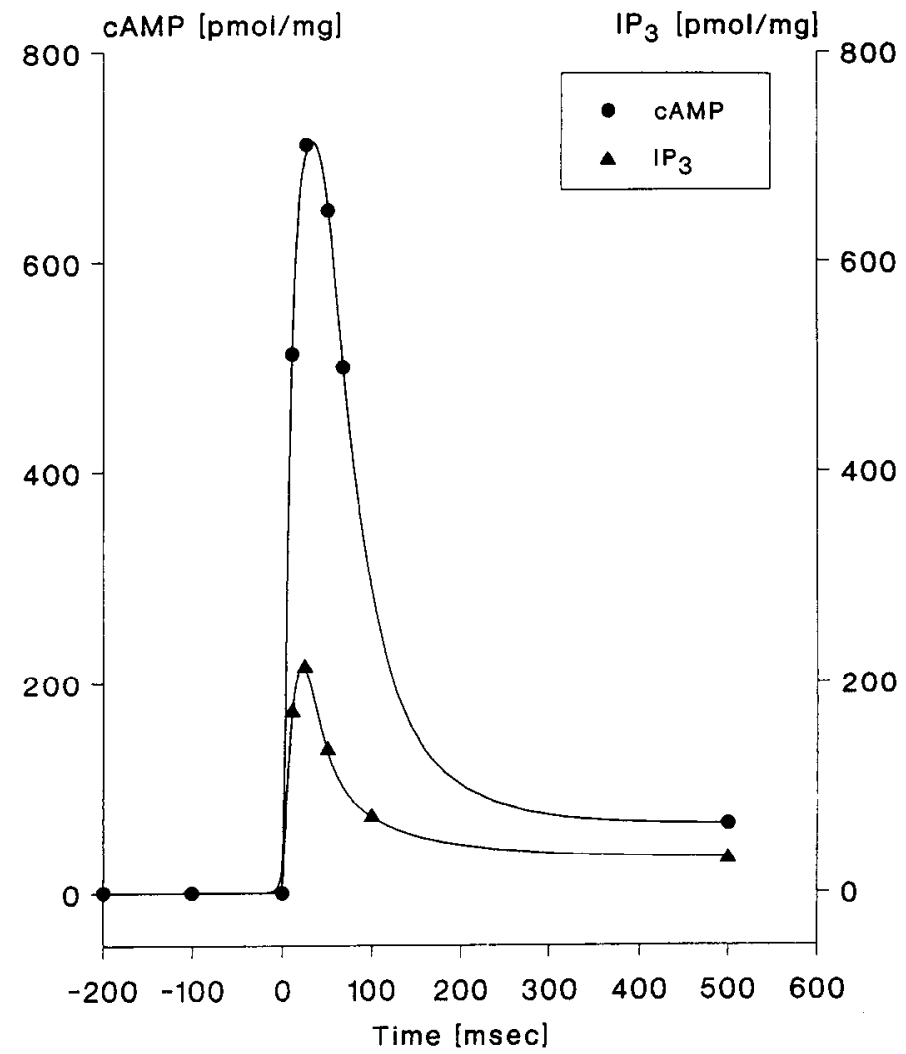

$100 \mu \mathrm{M}$ Taurine

$100 \mu \mathrm{M}$ Proline

Figure 4. Plot of the time course of stimulation of cAMP and $\mathrm{IP}_{3}$ in the outer dendritic membranes of lobster olfactory receptor cells by $100 \mu \mathrm{M}$ taurine $(A)$ and $100 \mu \mathrm{M}$ proline $(B)$. Coordinates are labeled as in Figure 1.

fective concentration of the single-component odors relative to the total concentration of stimulatory molecules in the complex odor.

A higher concentration of taurine and proline $(100 \mu \mathrm{M})$ elicited a significantly stronger signal; the peak response increased by a factor of 4-5 in both instances. More importantly, each odor at a concentration of $100 \mu \mathrm{M}$ elevated both signals (Fig. 4). The pattern of selectivity shown at $1 \mu \mathrm{M}$ was retained; taurine preferentially stimulated $\mathrm{IP}_{3}(630 \mathrm{pmol} / \mathrm{mg})$ over cAMP (280 pmol/ Ing) (Fig. 4A), while proline preferentially stimulated cAMP (720 pmol $/ \mathrm{mg}$ ) over $\mathrm{IP}_{3}(220 \mathrm{pmol} / \mathrm{mg}$ ) (Fig. $4 B)$. The differential ability of each odor to stimulate the two signals is consistent with the results of the physiological experiments indicating that an odor that excites one cell can inhibit another.

Dose-response experiments indicate that the ability of taurine and proline to stimulate both signals was concentration dependent (Fig. 5). The more potent odor stimulated measurable increases in $\mathrm{IP}_{3}$ (taurine, Fig. 5A) and cAMP (proline, Fig. 5B) down to nanomolar concentrations. Maximal stimulation of $\mathrm{IP}_{3}$ (330 pmol/mg) and cAMP (520 pmol/mg) occurred at about $100 \mu \mathrm{M}$ concentration of the more potent odor. Stimulation by the less potent odor was detectable only at concentrations between 1 and $10 \mu \mathrm{M}$ and failed to saturate in each case. In both instances, the odor was 100-1000 times more efficient for stimulating the predominant pathway. The differential stimulation of $\mathrm{IP}_{3}$ and cAMP by taurine (Fig. $5 A$ ) and proline (Fig. $5 B$ ), respectively, persisted over at least 6 orders of magnitude of odor concentration. As only two single-component odors were tested, it is uncertain whether all single-component odors would stimulate both sccond messcngers. A survey of the odor specificity of the two second messenger pathways will be the focus of a subsequent study.

\section{Discussion}

The observation that CAMP and $\mathrm{IP}_{3}$ responses peak within 50 msec of mixing with odors (Fig. 1) is consistent with the idea that odor-induced pulses of intracellular second messengers precede, and presumably drive, the physiological response of the cell. Lobsters actively sample their odor environment with a behavior functionally equivalent to sniffing in mammals. Odors evoke action potentials in the intact organ towards the end of the approximately $100 \mathrm{msec}$ acquisition period of this behavior (Schmitt and Ache, 1979). Maximal stimulation of either ligand within $50 \mathrm{msec}$ would be sufficiently fast to drive the physiological response in vivo, allowing several tens of milliseconds for channel activation, passive spread of the reccptor potential, action potential generation, and propagation to the recording site. Odor-evoked inward (and outward) currents can be recorded within $20 \mathrm{msec}$ of odor stimulation in cultured lobster olfactory receptor cells (Fadool et al., 1993), which would be cotemporal with the rising phase of the odor-induced pulse of cAMP or $\mathrm{IP}_{3}$ as measured in vitro. Odors stimulate cAMP and $\mathrm{IP}_{3}$ formation equally fast in vitro in olfactory cilia from rats (Breer et al., 1990) and catfish (Restrepo et al., 1993), where 
A

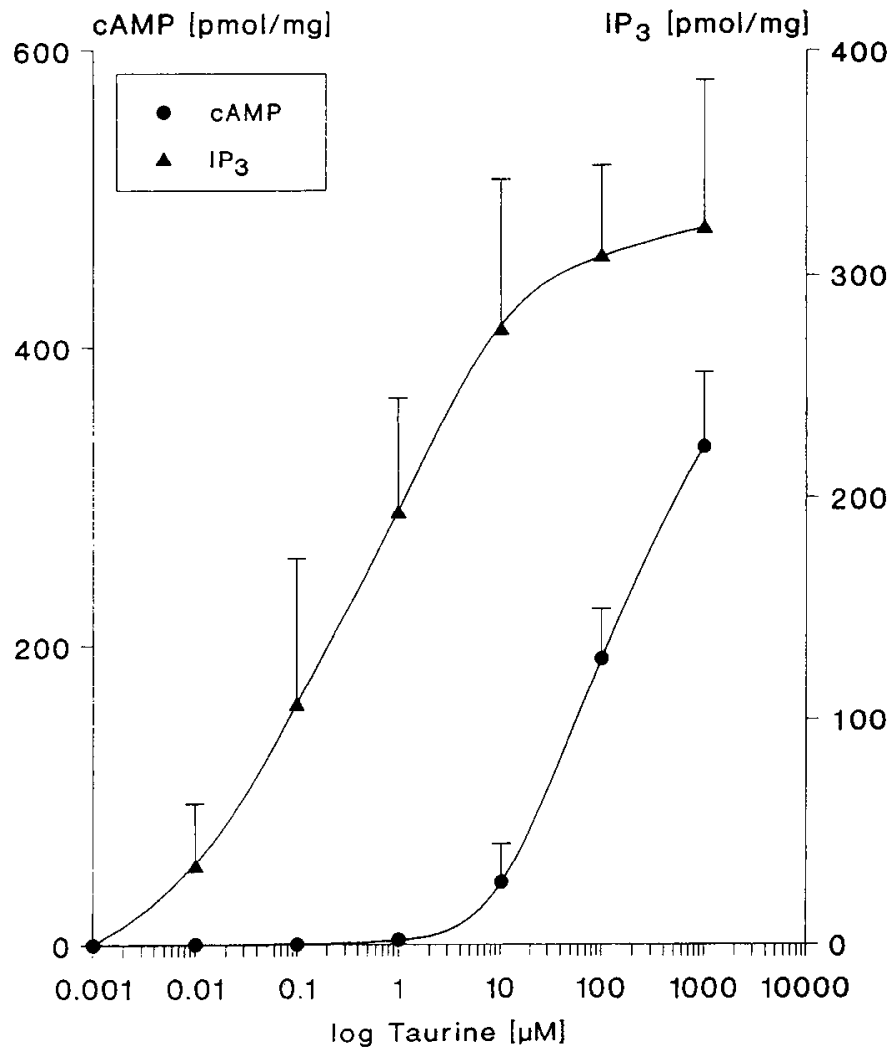

B

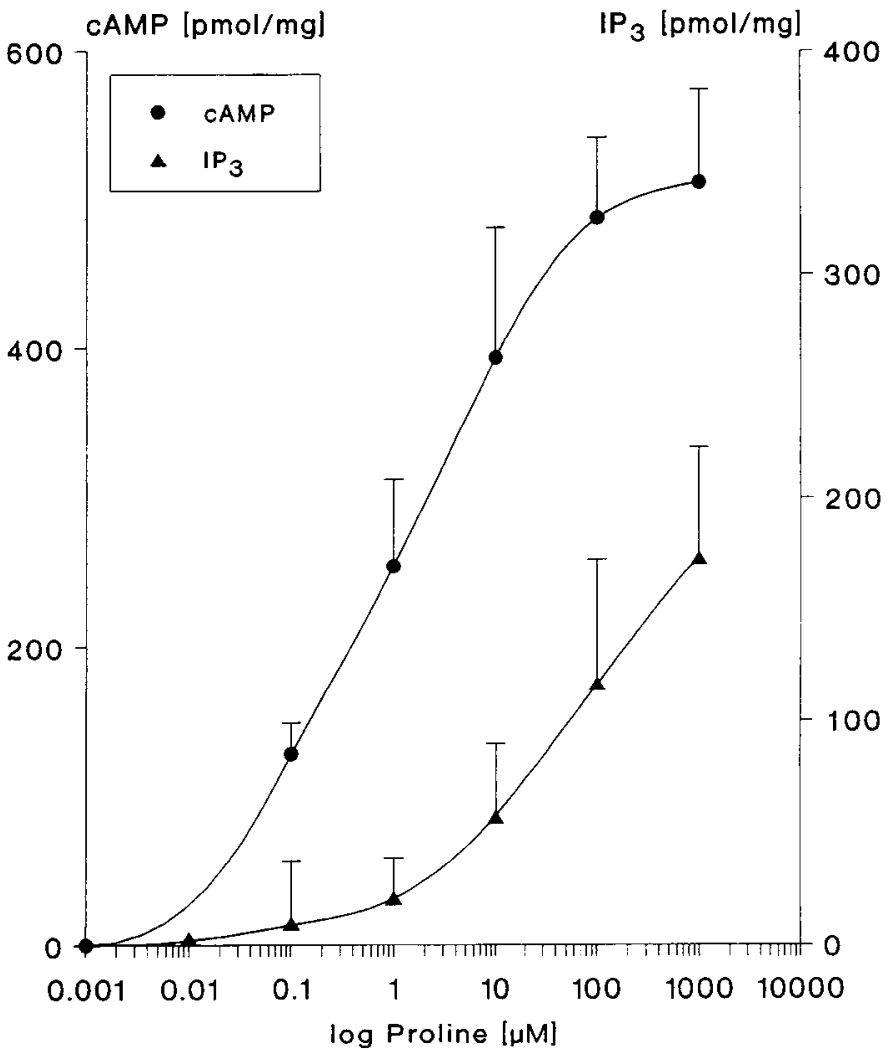

Figure 5. Plot of the dependency of stimulation of cAMP and $\mathrm{IP}_{3}$ in the outer dendritic membranes of lobster olfactory receptor cells at $t=50$ msec on the concentration of taurine $(A)$ and proline $(B)$. Ordinate is labeled as in Figure 1 ; abscissa, log concentration (micromolar) of odor. Values plotted represent mean \pm SE of a minimum of three trials per point.

they also are suspected to serve as second messengers. We conclude, therefore, that the odor-stimulated production of cAMP and $\mathrm{IP}_{3}$ is sufficiently rapid to account for both ligands serving as second messengers in lobster olfactory receptor cells.

The ability of two different odors (proline, taurine) to stimulate rapidly and transiently both second messengers (Fig. 4) is novel and is consistent with the recent finding of Ronnett et al. (1993) demonstrating that odors that elevate cAMP also increase the turnover of phosphoinositide in cultured rat olfactory receptor cells. The inability of either odor to stimulate both second messengers in the lobster at a 100-fold lower concentration (Fig. 3) provides a possible explanation for the apparent discrepancy between the present findings and the results of similar experiments on isolated rat olfactory cilia (Boekhoff et al., 1990; Breer et al., 1990), where odors at $1 \mu \mathrm{M}$ concentration exclusively stimulated cAMP or $\mathrm{IP}_{3}$. In the lobster, the weaker of the two signals in each case (Fig. 5) drops out or is not significantly above background at $1 \mu \mathrm{M}$; only the stronger of the two signals is significantly above background into the nanomolar range. Thus, the concentration of odor tested in the isolated rat olfactory cilia could have been too low to see significant stimulation of both signals. While millimolar amino acids rapidly and transiently stimulate only $\mathrm{IP}_{3}$ and not cAMP in isolated catfish olfactory cilia (Restrepo et al., 1993), the apparent selectivity in this particular instance could well reflect the type, and possibly the limited number $(n=6)$, of odors tested. Physiological and biochemical evidence suggest that, in catfish, amino acid odors are not directly linked to the cAMP pathway
(Bruch and Teeter, 1990; Restrepo et al., 1993). Although only two amino acids were tested in the present study, they were selected for their known opposing electrophysiological effects.

The ability of higher concentrations of proline and taurine to elevate both cAMP and $\mathrm{IP}_{3}$ raises the possibility of having two different receptor subtypes for those odors, each coupled to a different second messenger pathway through distinct G-proteins. This situation would be reminiscent of the various families of receptor subtypes for neurotransmitters. At first glance, the apparent 100-1000-fold lower affinity for stimulation of the weaker of the two signals by proline and taurine (Fig. 5) would seem to argue against this possibility and suggest that stimulation of the suboptimal signal is mediated by less-specific activation of receptors tuned to other odors. Our physiological observation that the incidence of taurine-evoked inhibition may be rare would be consistent with this interpretation. However, the weaker of the two signals failed to saturate, so the actual $K_{D}$ values cannot be estimated from the curves. There was no physiological evidence of nonspecific activation of the cAMP pathway by taurine, that is, no evidence that taurine weakly inhibited cells, although the magnitude of a nonspecific effect on a cell might be too small to measure. Blocking taurine-evoked excitation ( $\mathrm{IP}_{3}$ mediated) in cultured ORNs with ruthenium red or flunarizine does not unmask an inhibitory component (Fadool and Ache, 1992), as might be expected if taurine was nonspecifically activating the cAMP pathway. Comparison of the two curves for proline (Fig. 5) perhaps makes a stronger casc for receptor subtypes. Although failure of the weaker $\left(\mathrm{IP}_{3}\right)$ signal to 
saturate prohibits comparison of actual $K_{D}$ values, submicromolar proline elevated both signals. Again in physiological experiments, this time in the cells in situ, pharmacologically blocking proline-evoked inhibition (cAMP mediated) does not unmask an excitatory response physiologically (Michel et al., 1991), as might be predicted if proline were nonspecifically activating the $\mathrm{IP}_{3}$ pathway. The collective data therefore are consistent with the possibility of having subtypes of ligand-specific receptor with different affinities for some odors.

The ability of proline and taurine to stimulate cAMP and IP ${ }_{3}$ in the outer dendrites correlated with the odors' ability to excite and inhibit the receptor cells. Taurine, which was more often excitatory at $1 \mathrm{mM}(31 \%$ vs $3 \%)$, stimulated more IP $_{3}$ than CAMP over most of the concentration range. Proline, which was more often inhibitory at $1 \mathrm{mM}$ ( $31 \%$ vs $23 \%)$, stimulated more cAMP than $\mathrm{IP}_{3}$ over the same range of concentrations (Fig. 5). This finding was perhaps fortuitous since there is no a priori reason that the ability of proline and taurine to stimulate cAMP and IP $_{3}$ needs to correlate with the odors' physiological effects; the efficacy of the second messenger pathways is unknown. Direct comparison of the biochemical and physiological effects was not possible since the stronger of the two signals appeared to saturate at or near $1 \mathrm{~mm}$, the concentration used to obtain the physiological results. Physiological results could not be obtained at lower concentrations without biasing our ability to detect the much smaller-magnitude inhibitory responses when recording from the electrotonically remote soma. Using a different experimental paradigm designed to determine the threshold for inhibition, however, we have shown that both excitation and inhibition occur in a graded manner down to micromolar concentrations (Michel et al., 1991).

The presence of $\mathrm{IP}_{3}$ as well as cAMP in the outer dendrites of the mature cell with kinetics of activation that are consistent with second messenger function strengthen the proposition (Ache, in press) that dual transduction pathways allow for excitatory and inhibitory input to the cells. Recent indirect evidence supports the notion that this idea may also hold for some vertebrate olfactory receptor cells. A mixture of three odors found to stimulate cAMP in rat olfactory cilia (Boekhoff et al., 1990) excite toad olfactory receptor cells by evoking an inward current (Bacigalupo et al., in press), while a mixture of three odors found to stimulate $I P_{3}$ in rat cilia inhibit the toad cells by evoking an outward current. These results raise the interesting possibility that cAMP and $\mathrm{IP}_{3}$ mediate opposing inputs in toad and lobster, but with opposite roles.

\section{References}

Ache B (in press) Towards a common strategy for transducing olfactory information. Semin Cell Biol, in press.

Ache B, Hatt H, Breer H, Boekhoff I, Zufall F (in press) Biochemical and physiological evidence for dual transduction pathways in lobster olfactory receptor neurons. Abstr Chem Senses, in press.

Anholt RRH (1993) Molecular neurobiology of olfaction. Crit Rev Neurobiol 7:1-22.

Bacigalupo J, Morales B, Ugarte G, Delgado R, Jorquera O, Labarca P (in press) Electrophysiological studies in toad olfactory receptor neurons. Abstr Chem Senses, in press.

Boekhoff I, Tareilus E, Strotmann J, Breer H (1990) Rapid activation of alternative second messenger pathways in olfactory cilia from rats by different odorants. EMBO J 9:2453-2458.
Bradford MM (1976) A rapid and sensitive method for the quantification of microgram quantities of protein utilizing the principle of protein-dye binding. Anal Biochem 72:248-254.

Breer $\mathrm{H}$, Boekhoff I (1992) Second messenger signalling in olfaction. Curr Opin Neurobiol 2:439-443.

Breer H, Boekhoff I, Tareilus E (1990) Rapid kinetics of second messenger formation in olfactory transduction. Nature 344:65-68.

Bruch RC, Teeter JH (1990) Cyclic AMP links amino acid chemoreceptors to ion channels in olfactory cilia. Chem Senses 15:419-430.

Dadi HK, Morris RJ (1984) Muscarinic cholinergic receptors in rat brain. Eur J Biochem 144:617-628.

Dionne VE (1992) Chemosensory responses in isolated olfactory receptor neurons from Necturus maculosus. J Gen Physiol 99:415-433.

Fadool DA, Ache BW (1992) Plasma membrane inositol 1,4,5-trisphosphate-activated channels mediate signal transduction in lobster olfactory receptor neurons. Neuron 9:907-918.

Fadool DA, Michel, WC, Ache BW (1993) Odor sensitivity of cultured lobster olfactory receptor neurons is not dependent on process formation. J Exp Biol 174:215-233.

Ivanova T, Caprio J (1992) Two transduction mechanisms in olfactory neurons. Soc Neurosci Abstr.

Kalinoski DL, Aldinger SB, Boyle AG, Huque T, Marecek JF, Prestwich GD, Restrepo D (1992) Characterization of a novel inositol 1,4,5trisphosphate receptor in isolated olfactory cilia. Biochem J 281:449456.

Lucero MT, Horrigan FT, Gilly WF (1992) Electrical responses to chemical stimulation of squid olfactory receptor cells. J Exp Biol 162: 231-249.

Michel WC, Ache BW (1992) Cyclic nucleotides mediate an odorevoked potassium conductance in lobster olfactory receptor cells. J Neurosci 12:3979-3984.

Michel WC, McClintock TS, Ache BW (1991) Inhibition of lobster olfactory receptor cells by an odor-activated potassium conductance. J Neurophysiol 65:446-453.

Miyamoto T, Restrepo D, Cragoe EJ Jr, Tecter JH (1992) IP IP $_{3}$ and cAMP-induced responses in isolated olfactory receptor neurons from the channel catfish. J Membr Biol 127:173-183.

Olson KS, Trapido-Rosenthal HG, Derby CD (1992) Biochemical characterization of independent olfactory receptor sites for 5 'AMP and taurine in the spiny lobster. Brain Res 583:262-270.

Palmer S, Hughes KT, Lee DY, Wakelam MJ (1989) Development of a novel, ins $(1,4,5) \mathrm{P}_{3}$-specific binding assay: its use to determine the intracellular concentration of ins $(1,4,5) \mathrm{P}_{3}$ in unstimulated and vasopressin-stimulated cells. Cell Signal 1:147-156.

Pershadsingh HA, McDonald JM (1980) A high affinity calcium-stimulated magnesium-dependent adenosine triphosphatase in rat adipocyte plasma membranes. J Biol Chem 255:4087-4093.

Restrepo D, Miyamoto T, Bryant BP, Teeter JH (1990) Odor stimuli trigger influx of calcium into olfactory neurons of the channcl catfish. Science 249:1166-1168.

Restrepo D, Boekhoff I, Breer H (1993) Rapid kinetic measurements of second messenger formation in olfactory cilia from channel catfish. Am J Physiol 264:C906-C911.

Ronnett GV, Snyder SH (1992) Molecular messengers of olfaction. Trends Neurosci 15:508-513.

Ronnett GV, Cho H, Hester LD, Wood SF, Snyder SH (1993) Odorants differentially enhance phosphoinositide turnover and adenylyl cyclase in olfactory receptor neuronal cultures. J Neurosci 13:17511758.

Schmiedel-Jakob I, Michel MC, Anderson PAV, Ache BW (1990) Whole cell recording from lobster olfactory receptor cells: multiple ionic bases for the receptor potential. Chem Senses 15:397-405.

Schmitt BC, Ache BW (1979) Olfaction: responses of a decapod crustacean are enhanced by flicking. Science 205:204-206.

Tovey KC, Oldham KG, Whelan JAM (1974) A simple direct assay for cyclic AMP in plasma and other biological samples using an improved competitive protein binding technique. Clin Chim Acta 56: 221-234. 